\title{
New approaches to modeling denitrification
}

\author{
Peter M. Groffman · Eric A. Davidson • \\ Sybil Seitzinger
}

Received: 1 December 2008/Accepted: 1 December 2008/Published online: 24 January 2009

(C) Springer Science+Business Media B.V. 2009

\section{Introduction}

Within the past few decades, humans have dramatically altered the earth's nitrogen (N) cycle. Introduction of reactive nitrogen $(\mathrm{N})$ into the biosphere by humans now exceeds the rate of biological $\mathrm{N}_{2}$-fixation in native terrestrial ecosystems (Galloway et al. 2004). This increased reactive $\mathrm{N}$ is due primarily to $\mathrm{N}$ fertilizer production and fossil fuel combustion used to support the food and energy demands of a rapidly expanding human population. The negative human and environment health effects of this increased N are many (Galloway et al. 2008; Howarth et al. 2005; UNEP and WHRC 2007).

Denitrification is the main process that permanently removes fixed $\mathrm{N}$ from the environment. Denitrification, the microbial production of $\mathrm{N}_{2}$ from nitrate and nitrite, is a facultative anaerobic process

P. M. Groffman $(\bowtie)$

Cary Institute of Ecosystem Studies, Box AB, Millbrook, NY 12545, USA

e-mail: groffmanp@ecostudies.org

E. A. Davidson

The Woods Hole Research Center, Falmouth, MA 025401644, USA

e-mail: edavidson@whrc.org

S. Seitzinger

Institute of Marine and Coastal Sciences, Rutgers

University, New Brunswick, NJ 08901, USA

e-mail: sybil@marine.rutgers.edu ("classical denitrification"); therefore, partially to fully saturated soils and aquatic sediments, and low oxygen waters are ideal sites for denitrification. We now know that denitrification occurs in almost all terrestrial, freshwater, coastal and (some) oceanic ecosystems, as well as human engineered systems (Seitzinger et al. 2006). Despite the large number of denitrification studies there are still only a few locations with measurements adequate to quantify denitrification rates, or to understand factors controlling denitrification, at the ecosystem scale. This also has severely limited development and incorporation of denitrification into models which are necessary to scale-up measurements to local ecosystem, regional or global scales.

A Denitrification Research Coordination Network (Denitrification RCN) was established in 2005, with the overall goal to develop a coordinated network of denitrification scientists from a wide array of disciplines, from molecular biology to ecosystem science, and from soil science to oceanography. The efforts of the Denitrification RCN are intended to advance quantification of denitrification rates, development of process-based relationships between rates of denitrification and controlling factors, and production of spatially explicit, process-based models that can be used to scale-up site specific measurements to ecosystem, regional and global scales. Specific objectives include facilitating the sharing of recent methodological advances in denitrification measurement and models, stimulating additional methodological 
improvements, enhancing coordination of research activities and facilitating new joint research programs in under-sampled ecosystems and geographical regions, promoting synthesis and integration at various scales, and catalyzing and stimulating interaction of scientists with policy-makers and managers on denitrification issues of concern to society. Key activities of the RCN include convening workshops on focused topics of measurement, modeling, and application of denitrification research and publishing products of those workshops for access by the relevant scientific, management, and policy communities. More information on the Denitrification $\mathrm{RCN}$ is available on its web site (www.denitrification.org).

This special issue of Biogeochemistry presents products from the first workshop in the Denitrification RCN series which had modeling denitrification as its primary focus. The current status as well as new advances in modeling denitrification in terrestrial, freshwater and marine environments are covered, with an overall emphasis on scaling up from small scales to whole watershed perspectives. The workshop brought together denitrification measurement and modeling perspectives united in the need for estimating denitrification rates at appropriate temporal and spatial scales. The comparative approach, encompassing terrestrial, freshwater and marine environments allowed for exploration of the larger question of "Where in time and space does denitrification have the biggest effects on ecosystems?"

\section{Starting at the top of the hill}

The most impressive anthropogenic nitrogen source is application of fertilizer to agricultural systems. Of particular interest are tile-drained corn and soybean agroecosystems in the US Midwest. David et al. (2009) compared predicted denitrification estimates for a range of annual, monthly and daily fluxes for a typical corn and soybean agroecosystem on a tile drained Mollisol from five models. Ten year average denitrification estimates were quite variable across the models, and model dynamics differed widely. For example, during a high precipitation year some models predicted large denitrification fluxes for a few days, others predicted large fluxes persisting for several weeks to months. Models also differed markedly in the way they depicted components of the $\mathrm{N}$ cycle that influence denitrification. Model comparisons suggest that there are still considerable shortcomings in the current state of knowledge of how the dynamic factors that control denitrification vary spatially and temporally. Hence, our ability to accurately predict denitrification fluxes from the dominant agroecosystem in the American Midwestern farm belt is quite uncertain at this time.

Much of the uncertainty in denitrification models arises from the high spatial and temporal variability of denitrification rates in the field. This variability was addressed in the paper by Tonitto et al. (2009) who modeled $\mathrm{N}_{2} \mathrm{O}$ flux from an Illinois agroecosystem using Monte Carlo sampling of field observations, providing an observation-based counterpoint to the simulation model outcomes described by David et al. (2009). The analysis produced a range of annual $\mathrm{N}_{2} \mathrm{O}$ gas flux estimates. Encouragingly, mean annual flux estimates overlapped with results from the inter-model comparison presented by David et al. (2009). Although these observation-based techniques lack the seasonal resolution of mechanistic models, this data-derived approach is a complementary benchmark for assessing model performance and suggests that a mixed measurement/modeling approach may be useful for evaluating the impact of agricultural policy on greenhouse gas emissions.

Uncertainty in denitrification models also derives from the fact that small areas (hotspots) and brief periods (hot moments) frequently account for a high percentage of the denitrification activity that occurs in both terrestrial and aquatic ecosystems. The paper by Groffman et al. (2009) reviews the prospects for incorporating these phenomena into terrestrial and aquatic denitrification models. Given the increasing availability of high temporal frequency climate data, models are promising tools for evaluating the importance of hot moments such as freeze-thaw cycles and drying/rewetting events. Spatial hotspots are less tractable due to our inability to get high resolution spatial approximations of denitrification drivers such as carbon substrate and nitrate supply.

\section{What happens to the nitrogen once it leaves the field?}

The Groffman et al. (2009) analysis of hotspots and hot moments also addresses the idea that certain 
components of the landscape, especially those that are connected to nitrogen-rich ecosystems such as fertilized crop fields function as hotspots, e.g., riparian zones, streams, estuaries. The paper by Tague (2009) focuses on these connections with an analysis of the hydrologic parameters that contribute to uncertainty in denitrification estimates with an eye towards how measured data, such as streamflow, could be used to reduce this uncertainty. The ability of ecohydrological models to capture hot-spot contributions to watershed scale denitrification varies strongly with landscape tessellation and calibration. Streamflow data can be used to calibrate water movement through watershed ecosystems, but high resolution depiction of the landscape is needed to effectively depict hotspots such as riparian zones.

\section{Losing nitrogen as it flows from the land to the sea}

The importance of lotic systems as sinks for nitrogen inputs is well recognized. Because a fraction of the nitrogen in streamflow is removed to the atmosphere via denitrification, there is a keen interest in understanding the factors that control the fate of nitrogen throughout the stream channel network. Alexander et al. (2009) used a dynamic stream transport model to assess biogeochemical (nitrate loadings, concentration, temperature) and hydrological (discharge, depth, velocity) effects on reach-scale denitrification and nitrate removal in the river networks of two watersheds having widely differing levels of nitrate enrichment, but nearly identical discharges. Results indicate that the percentage of the stream nitrate flux removed via denitrification per unit length of channel is appreciably reduced during months with high discharge and nitrate flux, and is increased during months of low discharge and flux. Streams of the highly nitrate-enriched watershed denitrified a lower percentage of the stream-borne $\mathrm{N}$ than similarly sized streams in the less nitrate-enriched watershed.

The paper by Böhlke et al. (2009) investigated the relationships between varying flow and nitrate concentrations and stream denitrification in more detail, with a focus on the Mississippi River basin. They measured denitrification at multiple scales over a range of flow conditions and $\mathrm{NO}_{3}^{-}$concentrations, comparing reach-scale measurements (in-stream mass transport and tracer tests) with local-scale in situ measurements (pore-water profiles, benthic chambers) and laboratory data (sediment core microcosms) to evaluate the factors affecting benthic denitrification both temporally (e.g., seasonal variation in $\mathrm{NO}_{3}^{-}$concentrations and loads, flood-related disruption and re-growth of benthic communities and organic deposits) and spatially (e.g., local stream morphology and sediment characteristics). Relationships between denitrification and stream $\mathrm{NO}_{3}^{-}$ concentration were derived and compared and combined with results from a recent spatial comparison of stream denitrification extending to lower $\mathrm{NO}_{3}^{-}$ concentrations (LINX2). This combined dataset encompassed over 3 orders of magnitude in $\mathrm{NO}_{3}^{-}$ concentration. Hypothetical models based on these results illustrate that regional regressions and simulations of benthic denitrification in stream networks might be improved by including a non-linear relationship between denitrification and stream $\mathrm{NO}_{3}^{-}$ concentration and accounting for temporal variation.

\section{It all ends up in the deep water (lakes and estuaries)}

Ultimately, $\mathrm{N}$ moving from $\mathrm{N}$-enriched terrestrial environments ends up in either lentic (lakes and reservoirs) or marine water bodies that have great potential to act as important sites for denitrification. Harrison et al. (2009) describe, evaluate, and apply a new, spatially explicit, annual-scale, global model of lentic N removal called NiRReLa (Nitrogen Retention in Reservoirs and Lakes). The NiRReLa model incorporates small lakes and reservoirs and allows for separate treatment and analysis of reservoirs and natural lakes. Model runs for the mid-1990s indicate that lentic systems are indeed important sinks for $\mathrm{N}$, with small lakes $\left(<50 \mathrm{~km}^{2}\right)$ being particularly important (almost half of the global total).

Much of the denitrification that occurs in open water bodies takes place in sediments. Fennel et al. (2009) review approaches to describing denitrification in aquatic sediments, ranging from mechanistic diagenetic models to empirical parameterizations of nitrogen fluxes across the sediment-water interface. They reevaluate published parameterizations of denitrification and recommend that future models of denitrification use (1) a combination of mechanistic 
diagenetic models and measurements where bottom waters are temporally hypoxic or anoxic, and (2) much simpler correlations between denitrification and sediment oxygen consumption for oxic bottom waters.

\section{Conclusions}

Denitrification remains one of the most challenging biogeochemical processes (Kulkarni et al. 2008). There is a great need for information on this process to address local, regional and global nitrogen problems, but methods for measurement are problematic in many systems (Groffman et al. 2006), and as our analysis here shows, there are no conclusively robust models suitable for regulatory assessments. In terrestrial ecosystems, several sophisticated models have been developed (Boyer et al. 2006), but data on $\mathrm{N}_{2}$ emissions from soils are generally lacking for model validation and evaluation. In aquatic ecosystems, methodologies for measuring $\mathrm{N}_{2}$ are better developed, but modeling the environmental drivers of denitrification has been more problematic (Boyer et al. 2006). Nevertheless, the model-data comparisons presented in this special issue make an important contribution by helping to identify gaps in our knowledge of how to simulate denitrification. Comparing the successes and failures of a variety of modeling approaches is a necessary step for charting the way forward and for advancing our understanding of the dynamic factors controlling denitrification in terrestrial, freshwater and coastal marine systems.

The Denitrification RCN will continue to facilitate advances in denitrification. Following the modeling workshop described here, we held a workshop on "Advancing Methods for Measuring Denitrification in Terrestrial and Aquatic Ecosystems," and a workshop on "Managing Denitrification in Human Dominated Landscapes" is scheduled for May 12-14, 2009. We believe that continued interaction between measurers, modelers and managers ultimately will lead to advances in denitrification. Managers can guide science with specific needs for information, and measurers and modelers can interact to produce and evaluate responses to these needs. Over time, this iterative process should lead to an improved basic science understanding of the denitrification process and tools useful for applied science questions related to nitrogen pollution issues.
Acknowledgments This paper is a product of a workshop on Denitrification Modeling Across Terrestrial, Freshwater, and Marine Systems, held November 28-30, 2006, at the Institute of Ecosystem Studies, Millbrook, NY, with support from the Denitrification Research Coordination Network of the National Science Foundation, award DEB0443439 and the Northeastern States Research Cooperative (Grant \# 02-CA-11242343-105). This work was partially supported by the Cooperative State Research, Education, and Extension Service, US Department of Agriculture, under Agreement No. 2007-51130-03873. We thank the workshop participants and the authors and reviewers of the manuscripts in this special issue.

\section{References}

Alexander RB, Böhlke JK, Boyer EW, David MB, Harvey JW, Mulholland PJ, Seitzinger SP, Tobias CR, Tonitto C, Wollheim WM (2009) Dynamic modeling of nitrogen losses in river networks unravels the coupled effects of hydrological and biogeochemical processes. Biogeochemistry. doi:10.1007/s10533-008-9274-8

Böhlke JK, Antweiler RC, Harvey JW, Laursen AE, Smith LK, Smith RL, Voytek MA (2009) Multi-scale measurements and modeling of denitrification in streams with varying flow and nitrate concentration in the upper Mississippi River basin, USA. Biogeochemistry. doi:10.1007/ s10533-008-9282-8

Boyer EW, Alexander RB, Parton WJ, Li CS, Butterbach-Bahl K, Donner SD, Skaggs RW (2006) Modeling denitrification in terrestrial and aquatic ecosystems at regional scales: current approaches and needs. Ecol Appl 16:21232142

David MB, Del Grosso SJ, Hu X, Marshall EP, McIssac GF, Parton WJ, Tonitto C, Youssef MA (2009) Modeling denitrification in a tile-drained, corn and soybean agroecosystem of Illinois, USA. Biogeochemistry. doi: 10.1007/s10533-008-9273-9

Fennel K, Brady D, DiToro D, Fulweiler RW, Gardner WS, Giblin A, McCarthy MJ, Rao A, Seitzinger S, ThouvenotKorppoo M, Tobias C (2009) Modeling denitrification in aquatic sediments. Biogeochemistry. doi:10.1007/s10533008-9270-z

Galloway JN, Dentener FJ, Capone DG, Boyer EW, Howarth RW, Seitzinger SP, Asner GP, Cleveland C, Green P, Holland E, Karl DM, Michaels AF, Porter JH, Townsend A, Vorosmarty C (2004) Nitrogen cycles: past, present and future. Biogeochemistry 70:153-226

Galloway JN, Townsend AR, Erisman JW, Bekunda M, Cai Z, Freney JR, Martinelli LA, Seitzinger SP, Sutton MA (2008) Transformation of the nitrogen cycle: recent trends, questions, and potential solutions. Science 320:889-892

Groffman PM, Altabet MA, Bohlke JK, Butterbach-Bahl K, David MB, Firestone MK, Giblin AE, Kana TM, Nielsen LP, Voytek MA (2006) Methods for measuring denitrification: diverse approaches to a difficult problem. Ecol Appl 16:2091-2122

Groffman PM, Butterbach-Bahl K, Fulweiler RW, Gold AJ, Morse JL, Stander EK, Tague CL, Tonitto C, Vidon P 
(2009) Challenges to incorporating spatially and temporally explicit phenomena (hotspots and hot moments) in denitrification models. Biogeochemistry. doi:10.1007/ s10533-008-9277-5

Harrison JA, Maranger RJ, Alexander RB, Giblin AE, Jacinthe P-A, Mayorga E, Seitzinger SP, Sobota DJ, Wollheim WM (2009) The regional and global significance of nitrogen removal in lakes and reservoirs. Biogeochemistry. doi:10.1007/s10533-008-9272-x

Howarth RW, Ramakrishna K, Choi E, Elmgren R, Martinelli L, Mendoza A, Moomaw W, Palm C, Boy R, Scholes M, Zhao-Liang Z (2005) Nutrient management, responses assessment. In: Chopra K, Leemans R, Kumar P, Simons $\mathrm{H}$ (eds) Ecosystems and human well-being, chapter 9, volume 3, policy responses, the millennium ecosystem assessment. Island Press, Washington, DC, pp 295-311

Kulkarni MV, Groffman PM, Yavitt JB (2008) Solving the global nitrogen problem: it's a gas!. Front Ecol Environ 4:199-206
Seitzinger SP, Harrison JA, Böhlke JK, Bouwman AF, Lowrance R, Peterson B, Tobias C, Van Drecht G (2006) Denitrification across landscapes and waterscapes: a synthesis. Ecol Appl 16:2064-2090

Tague C (2009) Modeling hydrologic controls on denitrification: sensitivity to parameter uncertainty and landscape representation. Biogeochemistry. doi:10.1007/s10533008-9276-6

Tonitto C, David MB, Drinkwater LE (2009) Modeling $\mathrm{N}_{2} \mathrm{O}$ flux from an Illinois agroecosystem using Monte Carlo sampling of field observations. Biogeochemistry. doi: 10.1007/s10533-008-9271-y

UNEP and WHRC (2007) Reactive nitrogen in the environment: too much or too little of a good thing. In: Davidson EA, Arden-Clarke C, Braun E (eds) The United Nations Environment Programme, Paris, France 